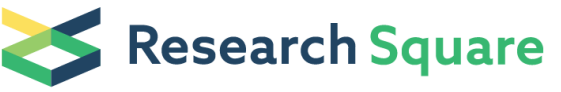 \\ Preprints are preliminary reports that have not undergone peer review. \\ They should not be considered conclusive, used to inform clinical practice, or referenced by the media as validated information.
}

\section{Honeycomb Wet Scrubber For Acidic Gas Control: Modeling And Long-term Test Results}

\section{Thi-Cuc Le}

National Chiao Tung University

\section{Gung-Hwa Hong}

National Chiao Tung University

Guan-Yu Lin

Tunghai University

\section{Ziyi Li}

University of Science and Technology Beijing

David Y.H. Pui

University of Minnesota

Yi-Ling Liou

Haze Control System Inc.

Bing-Tsai Wang

Pluto Co., Ltd

Chuen-Jinn Tsai ( $\nabla$ cjtsai@nctu.edu.tw)

Institute of Environmental Engineering, National Chiao Tung University, Hsinchu 30010, Taiwan https://orcid.org/0000-0002-0459-3232

\section{Research}

Keywords: Honeycomb, Wet scrubber, Acidic gas, Long-term operation, Pressure drop

Posted Date: January 13th, 2021

DOI: https://doi.org/10.21203/rs.3.rs-143724/v1

License: (c) (i) This work is licensed under a Creative Commons Attribution 4.0 International License.

Read Full License 


\section{1} term test results

3 Thi-Cuc Le ${ }^{1}$, Gung-Hwa Hong ${ }^{1}$, Guan-Yu Lin², Ziyi Li ${ }^{3}$, David Y.H. Pui ${ }^{4}, 5$, Yi-Ling Liou ${ }^{6}$, Bing-Tsai

$$
\text { Wang }{ }^{7} \text {, Chuen-Jinn Tsai }{ }^{1 *}
$$

$5 \quad{ }^{1}$ Institute of Environmental Engineering, National Chiao Tung University, Hsinchu 30010, Taiwan

$6 \quad{ }^{2}$ Department of Environmental Science and Engineering, Tunghai University, Taichung 407, Taiwan

$7 \quad{ }^{3}$ School of Energy and Environmental Engineering, University of Science and Technology Beijing,

8 Beijing 100083, China

$9 \quad{ }^{4}$ Mechanical Engineering Department, University of Minnesota, Minneapolis 55415, USA

10 5School of Science and Engineering, The Chinese University of Hong Kong, Shenzhen 518000,

11 China

$12{ }^{6}$ Haze Control System Inc., Hsinchu 30010, Taiwan

$13 \quad{ }^{7}$ Pluto Co. Ltd., Taoyuan 320, Taiwan

14

17 * Correspondence: cjtsai@nctu.edu.tw 


\section{Abstract}

A laboratory scale, 1.0 CMM wet scrubber packed with water-absorbing honeycomb material (HWS) with a very large geometric surface area of $480 \mathrm{~m}^{2} \mathrm{~m}^{-3}$ and a low pressure drop developed in our previous study was shown to achieve a very high removal efficiency for gaseous acidic gases but there were no long-term test data. In this study, the HWS scaled up to operate at 100 CMM flow rate was tested for removing mixed acidic gases at a semiconductor fab for a very long period of 3.5 years. Results showed that the removal efficiency for the mixed gases emitted from the fab always maintained as high as $>95 \%$ for $\mathrm{HF}, \mathrm{CH}_{3} \mathrm{COOH}, \mathrm{HCl}, \mathrm{HNO}_{3}, \mathrm{HNO}_{2}$, and $\mathrm{H}_{2} \mathrm{SO}_{4}$ with the inlet concentrations ranging from supper-ppmv to sub-ppmv, respectively, during 3.5-yr period. With water jet cleaning of the honeycomb modules once per year, the pressure drop of the HWS remained to be very low at 0.5 $0.8 \mathrm{cmH}_{2} \mathrm{O}$, indicating minimal scaling in the HWS existed. Additionally, the predicted height and removal efficiencies of the HWS were very close to the experimental data. The excellent long-term performance of the HWS warrants its potential applications in many areas in which liquid absorption is the preferred treatment method and the theoretical equations can facilitate the design of the HWS.

Keywords: Honeycomb, Wet scrubber, Acidic gas, Long-term operation, Pressure drop 


\section{Introduction} Inorganic acids such as $\mathrm{HF}, \mathrm{HCl}, \mathrm{HNO}_{3}, \mathrm{H}_{2} \mathrm{SO}_{4}$, and $\mathrm{CH}_{3} \mathrm{COOH}$ are widely used in

37

38

semiconductor or photoelectric manufacturing factories (or fabs) for wafer cleaning and wet-etching

processes [1-5] resulting in the emission of gaseous inorganic acidic pollutants from the stacks, which need to be treated to meet the emission standard of TWEPA (Taiwan Environment Protection Agency).

The standard stipulates that the total mass emission rate from all stacks must be $<0.6 \mathrm{~kg} \mathrm{~h}^{-1}$ for HF, $\mathrm{HCl}$, and $\mathrm{HNO}_{3}$, and $<0.1 \mathrm{~kg} \mathrm{~h}^{-1}$ for $\mathrm{H}_{2} \mathrm{SO}_{4}$, respectively, for a semiconductor fab, and the removal efficiency for each species must be $\geq 95 \%$ [1]. Among these gaseous pollutants, $\mathrm{HF}$ and $\mathrm{HCl}$ are considered as hazardous air pollutants [6]. These gases are also precursors for secondary inorganic components in $\mathrm{PM}_{2.5}$ [7] which is considered as a major health-risk concern in many countries [8]. Wet scrubbers (WSs) are widely used to control the emission of the acidic gases [9-11] due to their small footprint, simple structure, and low capital cost [12]. However, the measured removal efficiency (RE) of most of the traditional WSs can't meet the required value of greater than 95\% [1]. For instance, the removal efficiency of a vertical packed WS with 1,500 CMM flow rate were 70.6-93.4\% for $\mathrm{HF}, \mathrm{HCl}$, $\mathrm{HNO}_{2}, \mathrm{HNO}_{3}$, and $\mathrm{CH}_{3} \mathrm{COOH}$ at a high-tech factory while the removal efficiency of a lab-scale packed WS with 0.6-1.8 CMM flow rate was found to be as low as 76.8\%-85.7\% for $\mathrm{H}_{2} \mathrm{SO}_{4}$ mist [13]. When the removal efficiency of the WSs can't meet the standard value, they must follow the design criteria 
52 and operating conditions in which the specific surface area of packing materials must be $\geq 90 \mathrm{~m}^{2} \mathrm{~m}^{-3}$,

53 the residence time through the scrubbing section must be $\geq 0.5 \mathrm{~s}$, a wetting factor must be $\geq 0.1 \mathrm{~m}^{3} \mathrm{~h}^{-}$

$54{ }^{1}$, and the $\mathrm{pH}$ of scrubbing liquid must be $\geq 7$ as shown in Table 1 [1].

55 Among all operating parameters, the inlet concentration was found to be the most important

56 parameter affecting the removal efficiency of the packed WS. The removal efficiency of a conventional

57 packed WS increased with the increasing inlet concentration at low inlet concentration $\left(\mathrm{C}_{\text {in }}\right)$ and

58 approached a constant value until $\mathrm{C}_{\text {in }}$ reached a certain value for $\mathrm{HF}, \mathrm{HCl}, \mathrm{HNO}_{3}, \mathrm{HNO}_{2}$, and

$59 \mathrm{CH}_{3} \mathrm{COOH}$ [14]. For example, the removal efficiency of a multistage dual-flow sieve plate WS was

$6093.8 \%$ as $\mathrm{C}_{\text {in }}$ was as high as $100-300 \mathrm{ppmv}$ for $\mathrm{HCl}$ [15] while a packed tower was found to have a

61 removal efficiency of less than $90 \%$ when $\mathrm{C}_{\mathrm{in}}$ was lower than 1.0 ppmv for $\mathrm{HF}$ and $\mathrm{HCl}[9,14]$. The

62 WSs normally have high pressure drop resulting in high power consumption and operation cost [13,

63 16]. For example, a WS installed mesh MV filters operated at 90 CMM flow rate achieved $>95 \%$

64 removal efficiency for $\mathrm{NH}_{3}\left(\mathrm{~L} / \mathrm{G}\right.$ of $\left.2.0 \mathrm{~L} \mathrm{~m}^{-3}\right)$ at a high pressure drop of $>1,411 \mathrm{~Pa}$ [17]. However,

65 there were no long-term test data provided. Therefore, it is a challenge to design a WS with a high

66 removal efficiency and low pressure drop which lasts for a long time in an actual plant.

67 The WSs are normally packed with random packing materials to enhance the removal efficiency.

68 The packing materials, which can be in the form of a saddle, ring or tellerette and made of ceramics, 
69 glass, metal, porcelain, steel or plastics [18, 19], should have a high specific surface area to maximize

70 the gas-liquid contact surface for mass transfer [20] and liquid holdup. The removal efficiencies of

71 acidic gases were found to increase when the packing material size decreased [21]. For instance, the

72 removal efficiency for $\mathrm{HCl}$ was increased by $2.0-3.5 \%$ when the specific surface area of packing balls

73 was increased from 150 to $224 \mathrm{~m}^{2} \mathrm{~m}^{-3}$ [22]. The packing materials also need to resist fouling and

74 corrosion, avoid particle clogging, and enhance water retention to minimize the pressure drop and

75 maintenance cost for long-term use. In addition, they need to provide good air distribution for uniform

76 absorption [13] and low pressure drop in the WSs. The pressure drop of a WS with conventional plastic

77 packing materials is about $413-830 \mathrm{~Pa}\left(4.2-8.5 \mathrm{cmH}_{2} \mathrm{O}\right)$ per meter of the packing column [23-25].

78 The removal efficiency can also be improved by increasing the $\mathrm{L} / \mathrm{G}$ ratio due to the increasing

79 gas-liquid contacting surface area. The removal efficiency could increase from $82.8 \%$ to $97.5 \%$ as the

$80 \mathrm{~L} / \mathrm{G}$ ratio was increased from 1.5 to $3.0 \mathrm{~L} \mathrm{~m}^{-3}$ [26]. However, a higher $\mathrm{L} / \mathrm{G}$ ratio will cause a higher

81 pressure drop [11, 23]. Adding surfactants in the scrubbing liquid can help enhance the removal

82 efficiency of the WSs due to the charge generation on the water surface by surfactants but the

83 surfactants are costly [10]. The overall efficiency of a packed WS for $\mathrm{NH}_{3}, \mathrm{HF}$, and $\mathrm{HCl}\left(\mathrm{C}_{\mathrm{in}}=0.2-3\right.$

84 ppmv) was reported to increase from $56 \%$ to $83 \%$ at $1.1 \mathrm{~s}$ residence time and $10 \mathrm{CMM}$ flow rate when

85 surfactants were added $[9,10]$. The $\mathrm{pH}$ of the scrubbing solution is another factor that affects the 
removal efficiency of the WSs for some weak acidic gases such as $\mathrm{CH}_{3} \mathrm{COOH}$ but not for strong acidic

87 gases such as $\mathrm{HCl}[11]$. There is no significant effect on the removal efficiency for $\mathrm{CH}_{3} \mathrm{COOH}$ when the $\mathrm{pH}$ is higher than 7.5 due to the gas dissolution limit while the removal efficiency for $\mathrm{HCl}$ and $\mathrm{HNO}_{3}$ is nearly constant for the $\mathrm{pH}$ ranging from 7-9 [11, 27]. To achieve good efficiency for mixed acidic gases and save the operating cost, the $\mathrm{pH}$ of scrubbing liquid should be maintained $>$ 7.5. Most of the previous researches have focused on enhancing removal efficiency of WSs by determining the optimal operating conditions $[16,26,28]$, attempting to improve the performance of the existing WSs operating in high-tech industries $[9,10,22]$, and designing lab-scale WSs for short-

94 term study only $[13,19,29]$. A WS packed with a multi-parallel-plate (MPP) module (PPWS)

95 developed by our group can achieve very high removal efficiencies for $\mathrm{HCl}(>99 \%), \mathrm{HNO}_{3}(>98 \%)$, and $\mathrm{CH}_{3} \mathrm{COOH}(>99 \%)$ and very low pressure drop (23.5 Pa) at a regulated residence time of $0.5 \mathrm{~s}$, a

97 low inlet concentration $(<3 \mathrm{ppmv})$, and a high $\mathrm{L} / \mathrm{G}$ ratio $\left(18.5 \mathrm{~L} \mathrm{~m}^{-3}\right)$ [11]. It is because that the PPWS uses polypropylene plates coated with nano- $\mathrm{TiO}_{2}$ packing material with $326.67 \mathrm{~m}^{2} \mathrm{~m}^{-3}$ specific surface area to enhance the hydrophilicity for scrubbing liquid to form a uniform liquid film. However, this packing material requires a time-consuming and meticulous procedure for preparation and assembly with a precise gap of $3 \mathrm{~mm}$. The pilot-scale 1.0 CMM WS with the honeycomb module (HWS) was

102 further developed with the removal efficiency as high as the PPWS and the packing module is easy to 
103 fabricate [14]. The HWS showed nearly $100 \%$ for $\mathrm{HF}\left(\mathrm{C}_{\mathrm{in}}=0.1-0.4 \mathrm{ppmv}\right)$ and $99 \%$ for $\mathrm{HCl}\left(\mathrm{C}_{\mathrm{in}}=\right.$

104 3.4-10.8 ppmv $)$ and $\mathrm{CH}_{3} \mathrm{COOH}\left(\mathrm{C}_{\mathrm{in}}=0.7-6.5 \mathrm{ppmv}\right)$ at an optoelectronic factory. Similar to the MPP

105 module, the honeycomb packing material made of water-absorbing polypropylene (PP) fabric $(0.875$

$\left.106 \mathrm{~kg} \mathrm{~m}^{-1}\right)$ shows the higher specific surface area $\left(483.2 \mathrm{~m}^{2} \mathrm{~m}^{-3}\right)$ and lower pressure drop than most of the

107 packing materials as shown in Table 2.

108 Thus, the honeycomb packing material with the uniform arrangement and 3-mm gap becomes a

109 promising packing material for an efficient WS. But the removal efficiency of these small scale HWS

110 and PPWS were obtained when these WSs were run for several days. There are no scale-up, actual

111 HWS which runs in a fab for the long-term to control the soluble gas emission. In this study, the HWS

112 was scaled up as an actual device in a semiconductor manufacturing fab at $100 \mathrm{CMM}$ flow rate to

113 remove acidic gases and odor. The removal efficiencies of the HWS for the mixed gases containing

$114 \mathrm{HF}, \mathrm{HCl}, \mathrm{HNO}_{3}, \mathrm{HNO}_{2}, \mathrm{H}_{2} \mathrm{SO}_{4}$, and $\mathrm{CH}_{3} \mathrm{COOH}$ were tested for 13 times over 3.5 years for the removal

115 efficiency while the pressure drop was also measured to make sure that there was no fouling occurred

116 in the system. The theoretical analysis was conducted to predict the height of the packing module and

117 the removal efficiency of the HWS and the traditional WS to further justify the outstanding

118 performance of the HWS.

\section{2. Materials and methods}


120

121

122

123

12

125

126

127

128

129

130

131

132 for acidic gases. In this study, the HWS with the specific surface area of the packing material of 480

$133 \mathrm{~m}^{2} \mathrm{~m}^{-3}$ was designed to operate at $100 \mathrm{CMM}$ flow rate with $0.4 \mathrm{~m} \mathrm{~s}^{-1}$ face velocity and $0.5 \mathrm{~s}$ retention

134 time. The liquid flow rate was about $2,600 \mathrm{~L} \mathrm{~min}^{-1}$ which was controlled by a flow meter and the $\mathrm{L} / \mathrm{G}$

135 ratio was maintained at $26 \mathrm{~L} \mathrm{~m}^{-3}$. NaOH solution was used as the scrubbing solution with the $\mathrm{pH}$

136

\subsection{Field test}

The experimental setup of the HWS installed at a semiconductor manufacturing fab which produces DRAM in Hsinchu, Taiwan to reduce its emission and bad odor of acidic gases is shown in Fig. 1a. The HWS, which is registered as a patent in Taiwan (No. I569867 and M466724), is an addon central scrubber device mainly to remove high concentration acidic gas pollutants collected from about 40 local scrubbers before a traditional central packed tower which has low removal efficiency with high emitted $\mathrm{HF}$ and $\mathrm{CH}_{3} \mathrm{COOH}$ concentrations (e.g., typically $>10$ ppmv without the present HWS) and bad odor. The HWS consists of 64 honeycomb modules placed in parallel in four rows (16 modules per row) as shown in Fig. 1b, spray nozzles installed at the top of honeycomb modules, and a liquid reservoir with conductivity and $\mathrm{pH}$ meters. Each honeycomb elements were scrolled in a cylindrical casing ( $\mathrm{D} \times \mathrm{Z}=300 \times 300 \mathrm{~mm}$ ). The operating parameters of the HWS are shown in Table 1, which meet the design criteria for a packed tower to achieve the efficiency-based emission standards maintained at 7.5-8. The theoretical pressure drop of $59.8 \mathrm{~Pa}\left(0.58 \mathrm{cmH}_{2} \mathrm{O}\right)$ was calculated by the 
137 method in Chien et al. [11], which is higher than the pressure drop (23.5 Pa) of the lab-scale, 1.0 CMM

138 HWS in the previous study due to the increasing $\mathrm{L} / \mathrm{G}$ ratio.

139 The HWS was tested for the removal efficiency of inorganic gaseous acidic pollutants including

$140 \mathrm{HF}, \mathrm{HCl}, \mathrm{HNO}_{2}, \mathrm{HNO}_{3}, \mathrm{H}_{2} \mathrm{SO}_{4}$, and $\mathrm{CH}_{3} \mathrm{COOH}$ from August 2016 to March 2020 (3.5 years) with 13

141 times (11/08/2016, 12/09, 11/10, 15/11, 13/12, 13/03/2017, 15/06, 15/08, 22/12, 02/05/2018,

$14231 / 01 / 2019,6 / 12$, and 19/03/2020). The testing frequency was set at once per month in the first 5

143 months (5 tests) and then extended to once per three months in the next 12 months (4 tests), once per

144 six months (2 tests), and finally once per year (1 test). The latest testing time (19/03/2020) was about

1453 months after the $12^{\text {th }}$ test when the $\mathrm{pH}$ meter was not functioning well when the $\mathrm{NaOH}$ solution was

146 not pumped into the tank to maintain the $\mathrm{pH} \geq 7.5$. The result of the $12^{\text {th }}$ test is shown in Fig. $\mathrm{S} 1$ in

147 Section S1 in the supplementary information (SI). Two porous denuder samplers (PDS) with a $2 \mathrm{~L} \mathrm{~min}^{-}$

$148{ }^{1}$ flow rate $[4,30-32]$ were used to sample mixture gases at the inlet and outlet of the HWS

149 simultaneously in 20-60 min depending on inlet concentrations. The PDS consists of a Teflon filter for

150 sampling particles followed by two porous-metal discs coated with solutions containing $10 \mathrm{ml}, 5 \%$

$151(\mathrm{w} / \mathrm{v})$ sodium carbonate and 1\% (w/v) glycerol in 1:1 (v/v) methanol/water solution for sampling

152 inorganic acidic and basic gases. An ion chromatography (model 883, Metrohm AG, Switzerland) was

153 used to quantify the concentrations of gases and particles. The particulate phase concentration was 
154 found to be much smaller than the corresponding gaseous species and is not a target of this study. The

$155 \mathrm{RE}$ of the acidic gases was then calculated as:

156

$157 \quad \mathrm{RE}(\%)=\left[1-\frac{C_{\text {out }}}{C_{\text {in }}}\right] \times 100 \%$

158

159 where $\mathrm{C}_{\text {out }}$ (ppbv) was the outlet concentrations of $\mathrm{HF}, \mathrm{HCl}, \mathrm{HNO}_{2}, \mathrm{HNO}_{3}, \mathrm{H}_{2} \mathrm{SO}_{4}$, or $\mathrm{CH}_{3} \mathrm{COOH}$ in

160 the gas phase. Four tons of makeup water per day was required to compensate for water evaporation

161 and maintain the conductivity of $0.3-0.5 \mathrm{mS} \mathrm{cm}^{-1}$ in the water reservoir. The pressure drop of the HWS

162 was also measured at five testing times (11/08/2016, 13/12, 15/08/2017, 31/01/2019, and 19/03/2020)

163 during the 3.5-yr period.

164 2.2. Theoretical prediction

165 The theoretical removal efficiency of the HWS is calculated by using Eqs. (2) and (3) and Eq. (4)

166 based on the convection-diffusion theory of Gormley and Kennedy $\left(\mathrm{RE}_{\mathrm{GK}}, \%\right)[33,34]$ and two film-

167 theory $\left(\mathrm{RE}_{\mathrm{CA}}, \%\right)[18]$, respectively, as follows:

168

169

$$
\mathrm{RE}_{G K}(\%)=[1-[0.82 \exp (-11.5 \xi)+0.097 \exp (-70.1 \xi)]] \times 100 \% \text { for } \xi<0.009
$$


171

$$
\mathrm{RE}_{G K}(\%)=\left[1-\left[1-5.50 \xi^{2 / 3}+3.77 \xi\right]\right] \times 100 \% \quad \text { for } \xi \geq 0.009
$$

172

173 where $\xi$ is the dimensionless parameter which is calculated as $\xi=\mathrm{D}_{\mathrm{g}} \mathrm{LZ} / \mathrm{QW}$, where $\mathrm{D}_{\mathrm{g}}$ is the diffusion

174 coefficient of the gaseous pollutant in the gas phase $\left(\mathrm{m}^{2} \mathrm{~s}^{-1}\right)$ and calculated by the Fuller-Schettler-

175 Giddings equation [35], $\mathrm{L}$ is the total length of the PP fabric plate ( $\mathrm{m})$; $\mathrm{Z}$ is the height of the honeycomb

176 module $(\mathrm{m})$; $\mathrm{W}$ is the gap of the module $(\mathrm{m}) ; \mathrm{Q}$ is the airflow rate $\left(\mathrm{m}^{3} \mathrm{~s}^{-1}\right)$. The $\mathrm{RE}_{\mathrm{CA}}$ is calculated as

$177 \quad[18]:$

178

179

$$
\mathrm{RE}_{C A}(\%)=\left[1-\exp \left(-\frac{Z K_{g} a_{t}}{G_{m y}}\right)\right] \times 100 \%
$$

180

181 where $a_{t}$ is the total specific surface area of the module $\left(\mathrm{m}^{2} \mathrm{~m}^{-3}\right) ; \mathrm{K}_{\mathrm{g}}$ is the overall mass transfer

182 coefficient $\left(\right.$ mole s ${ }^{-1} \mathrm{~m}^{-2}$ ) which is calculated as $1 / \mathrm{K}_{\mathrm{g}}=1 / \mathrm{k}_{\mathrm{g}}+\mathrm{m} / \mathrm{k}_{\mathrm{w}}$ in which $\mathrm{k}_{\mathrm{g}}$ and $\mathrm{k}_{\mathrm{w}}$ are the mass

183 transfer coefficient of the gaseous pollutants in the gas phase and the liquid phase, respectively (mole

$\left.184 \mathrm{~s}^{-1} \mathrm{~m}^{-2}\right)$ and $\mathrm{m}$ is the dimensionless Henry's law constant $(\mathrm{H})$ or the dimensionless effective Henry's

185 law constant $\left(H^{*}\right) ; G_{m y}$ is the molar flux of the air through the HWS and calculated as $G_{m y}=V_{m} / S$ in

186 which $\mathrm{V}_{\mathrm{m}}$ is the molar flow rate of the air $\left(\right.$ mole $\left.\mathrm{s}^{-1}\right)$ and $\mathrm{S}$ is the empty cross-sectional area of the

187 honeycomb module $\left(\mathrm{m}^{2}\right)$. 


$$
k_{g}=\frac{0.023 \pi N_{R e}^{0.83} N_{S C}^{0.44} D_{g} \mathrm{P}}{W}
$$

192

$$
k_{w}=0.422 \sqrt{\frac{D_{w} \Gamma}{\rho_{w} B_{F}^{2}}}
$$

193

194 where $\mathrm{P}$ is the total pressure (atm); $\mathrm{N}_{\mathrm{Re}}$ is the Reynolds number which is calculated as $\mathrm{N}_{\mathrm{Re}}=\mathrm{W}^{\prime} \mathrm{G}_{\mathrm{g}} / \mu_{\mathrm{g}}$, 195 where $\mathrm{W}^{\prime}$ is the equivalent inner diameter of the honeycomb module $(\mathrm{m})$ which is calculated as $\mathrm{W}^{\prime}=$ 196 $\sqrt{4 S / \pi}, \mathrm{G}_{\mathrm{g}}$ is the mass flow rate of the air $\left(\mathrm{kg} \mathrm{s}^{-1} \mathrm{~m}^{-2}\right)$, and $\mu_{\mathrm{g}}$ is the air viscosity $\left(\mathrm{kg} \mathrm{m}^{-1} \mathrm{~s}^{-1}\right)$; $\mathrm{N}_{\mathrm{sc}}$ is the

197 Schmidt number and calculated as $\mathrm{N}_{\mathrm{Sc}}=\mu_{\mathrm{g}} / \rho_{\mathrm{g}} \mathrm{D}_{\mathrm{g}}$ in which $\rho_{\mathrm{g}}$ is the air density $\left(\mathrm{kg} \mathrm{m} \mathrm{m}^{-3}\right) ; \mathrm{D}_{\mathrm{w}}$ is the 198 diffusion coefficient of the gaseous pollutant in the liquid phase $\left(\mathrm{m}^{2} \mathrm{~s}^{-1}\right)$ which is calculated by the

199 Stokes-Einstein equation [37]; $\Gamma$ is the liquid mass flow rate based on the wetted perimeter $\left(\mathrm{kg} \mathrm{s}^{-1} \mathrm{~m}^{-}\right.$

$\left.200{ }^{1}\right) ; \rho_{\mathrm{w}}$ is the liquid density $\left(\mathrm{kg} \mathrm{m}^{-3}\right) ; \mathrm{B}_{\mathrm{F}}=\left(3 \mu_{\mathrm{w}} \Gamma / \rho_{\mathrm{w}} \mathrm{g}\right)^{1 / 3}$ in which $\mu_{\mathrm{w}}$ is the liquid viscosity $\left(\mathrm{kg} \mathrm{m}^{-1} \mathrm{~s}^{-1}\right)$

201 and $\mathrm{g}$ is the gravity acceleration $\left(\mathrm{m} \mathrm{s}^{-2}\right)$.

202 The theoretical height of the honeycomb module $\left(Z_{\mathrm{CA}}, \mathrm{m}\right)$ can be calculated as [18]:

203

204

$$
Z_{C A}=\left[\frac{G_{m y}}{K_{g} a_{t}}\right] \times\left[\int_{C_{\text {out }}}^{C_{\text {on }}} \frac{d C}{\left(1-m \frac{V_{m}}{L_{m}}\right) C+\left(\frac{V_{m}}{L_{m}} C_{\text {in }}-C_{w, \text { out }}\right)}\right]
$$


206 where $\mathrm{L}_{\mathrm{m}}$ is the liquid molar flow rate (mole s$\left.{ }^{-1}\right) ; \mathrm{C}_{\mathrm{w}, \text { out }}$ is the outlet concentration of the gaseous 207 pollutant in the liquid phase (ppbv) and it is calculated as $\mathrm{C}_{\mathrm{w}, \text { out }}=\mathrm{C}_{\mathrm{w}, \text { in }}+\left(\mathrm{V}_{\mathrm{m}} / \mathrm{L}_{\mathrm{m}}\right) \times\left(\mathrm{C}_{\mathrm{in}}-\mathrm{C}_{\text {out }}\right)$ in which $208 \mathrm{C}_{\mathrm{w} \text {,in }}$ is the inlet concentration of the gaseous pollutant in the liquid phase (ppbv). Assuming that the 209 honeycomb modules are replaced by the traditional packing materials, the removal efficiency of the 210 wet scrubber packed with different raschig rings (equivalent diameter $\left(D_{e}\right)=6,13$ and $25 \mathrm{~mm}$ ) and 211 berl saddle $\left(D_{e}=25 \mathrm{~mm}\right)$ are studied. The small raschig rings with $\mathrm{D}_{\mathrm{e}}$ equal to $6 \mathrm{~mm}$ and $13 \mathrm{~mm}$ have 212 the specific surface areas $50 \%$ higher than $\left(710 \mathrm{~m}^{2} \mathrm{~m}^{-3}\right)$ and similar $\left(370 \mathrm{~m}^{2} \mathrm{~m}^{-3}\right)$ [36] to that of the 213 honeycomb module, respectively. Whereas, the commonly used raschig ring $\left(D_{e}=25 \mathrm{~mm}\right.$ and $\mathrm{a}_{\mathrm{t}}=190$ $\left.214 \mathrm{~m}^{2} \mathrm{~m}^{-3}\right)$ [36] and berl saddle $\left(\mathrm{D}_{\mathrm{e}}=25 \mathrm{~mm}\right.$ and $\left.\mathrm{a}_{\mathrm{t}}=250 \mathrm{~m}^{2} \mathrm{~m}^{-3}\right)$ [36] have the specific surface areas 215 much lower than that of the honeycomb module. The gas phase and liquid phase mass transfer 216 coefficients of the WS packed with the raschig rings and berl saddle are typically calculated by Eqs.

217 (S1) and (S2), respectively shown in Section S2 in the SI. The theoretical height of the raschig rings 218 and the berl saddle is then calculated by Eq. (8) and compared with that of the honeycomb module.

219 The pressure drop of the traditional WS is determined based on the correlation of $\frac{U_{t}{ }^{2} a_{t} \rho_{g} \mu_{w}{ }^{0.2}}{g \epsilon^{2} \rho_{w}}$ and $220 \frac{G_{W}}{G_{g}} \sqrt{\frac{\rho_{g}}{\rho_{w}}}$ and compared to that of the HWS [36].

\section{3. Results and discussion}


222

223

224

225

226

227

228

229

230

23

232

233

234

235

236

237

238

\subsection{Field test results}

Fig. 2 shows the removal efficiency of the HWS versus time with a wide range of the inlet concentrations of 31,874-180,685 ppbv for $\mathrm{HF}, 12,552-72,582 \mathrm{ppbv}$ for $\mathrm{CH}_{3} \mathrm{COOH} ; 1,384-15,203$ ppbv for $\mathrm{HCl}, 1,234-12,390$ ppbv for $\mathrm{HNO}_{3}, 201-6,017$ ppbv for $\mathrm{HNO}_{2}$, and 240-1,583 ppbv for $\mathrm{H}_{2} \mathrm{SO}_{4}$. Among these gases, $\mathrm{HF}$ and $\mathrm{CH}_{3} \mathrm{COOH}$ are dominant and constitute $64.3 \pm 9.95$ and $25.4 \pm$ $9.3 \%$ of the total mass concentration of the mixed gases, respectively while $\mathrm{HCl}, \mathrm{HNO}_{3}, \mathrm{HNO}_{2}$, and $\mathrm{H}_{2} \mathrm{SO}_{4}$ account for only $4.0 \pm 1.7 \%, 3.5 \pm 1.7 \%, 2.1 \pm 1.4 \%$, and $0.6 \pm 0.3 \%$, respectively. The figure shows that the removal efficiencies of each species are all very high, which are $95.6-98.3 \%\left(\mathrm{RE}_{\mathrm{ave}}=\right.$ $97.2 \pm 0.8 \%$ ) for $\mathrm{HF}$ (Fig. 2a), 95.0-98.3\% $\left(\mathrm{RE}_{\mathrm{ave}}=96.9 \pm 1.1 \%\right)$ for $\mathrm{CH}_{3} \mathrm{COOH}($ Fig. 2a), 96.1-98.5\% $\left(\mathrm{RE}_{\mathrm{ave}}=97.7 \pm 0.7 \%\right)$ for $\mathrm{HCl}$ (Fig. 2 b), 95.1-98.8\% $\left(\mathrm{RE}_{\mathrm{ave}}=97.5 \pm 1.2 \%\right)$ for $\mathrm{HNO}_{3}$ (Fig. 2b), 95.097.9\% $\left(\mathrm{RE}_{\mathrm{ave}}=96.3 \pm 0.9 \%\right)$ for $\mathrm{HNO}_{2}$ (Fig. 2c), and 95.2-97.6\% $\left(\mathrm{RE}_{\mathrm{ave}}=96.5 \pm 0.7 \%\right)$ for $\mathrm{H}_{2} \mathrm{SO}_{4}$

(Fig. 2c), respectively. That is, the HWS shows a very good performance for mixed gas control with a wide inlet concentration range during the 3.5-yr long period.

The removal efficiency of the acidic gases follows the order as $\mathrm{HCl}>\mathrm{HNO}_{3}>\mathrm{HF}>\mathrm{HNO}_{2}>\mathrm{CH}_{3} \mathrm{COOH}>\mathrm{H}_{2} \mathrm{SO}_{4}$. Among these gases, $\mathrm{HCl}$ has the highest removal efficiency during 3.5 years although $\mathrm{HCl}$ has the lowest $\mathrm{H}\left(\mathrm{H}_{\mathrm{HCl}}=1.1<\mathrm{H}_{\mathrm{HNO} 2}=49<\mathrm{H}_{\mathrm{CH} 3 \mathrm{COOH}}=8.8\right.$ $\left.\times 10^{3}<\mathrm{H}_{\mathrm{HF}}=1.3 \times 10^{4}<\mathrm{H}_{\mathrm{HNO} 3}=2.1 \times 10^{5}<\mathrm{H}_{\mathrm{H} 2 \mathrm{SO} 4}=2.9 \times 10^{9} \mathrm{M} \mathrm{atm}^{-1}\right)[38,39]$. On the other hand, 
239 the dissociation constants of $\mathrm{HCl}\left(\mathrm{K}_{\mathrm{HCl}}=1.7 \times 10^{6} \mathrm{M} \mathrm{atm}^{-1}\right)$ is several orders of magnitude higher than 240 other acidic gases $\left(\mathrm{K}_{\mathrm{H} 2 \mathrm{SO} 4}=10^{3}, \mathrm{~K}_{\mathrm{HNO} 3}=15.4 ; \mathrm{K}_{\mathrm{HF}}=6.3 \times 10^{-4} ; \mathrm{K}_{\mathrm{HNO} 2}=5.1 \times 10^{-4} ; \mathrm{K}_{\mathrm{CH} 3 \mathrm{COOH}}=1.7\right.$

$\left.241 \times 10^{-5} \mathrm{M} \mathrm{atm}^{-1}\right)[11,38]$. It indicates that $\mathrm{H}$ just reflects the physical solubility of the gases while 242 additional dissociation and chemical reaction constants also play role in the absorption process by WSs $243[16,38]$, which is explained in detail in Section 3.2.

244 It is seen that the high removal efficiency of the HWS does not change from the first operating 245 day (11/08/2016) until the latest testing day (19/03/2020) for $\mathrm{CH}_{3} \mathrm{COOH}\left(1^{\text {st: }}: 96.3 \% ; 13^{\text {th: }}: 97.4 \%\right)$ and $246 \mathrm{HCl}\left(1^{\text {st. }}: 97.8 \% ; 13^{\text {th. }}: 97.8 \%\right)$, respectively, while it is slightly decreases for $1.3 \%$ for $\mathrm{HF}\left(1^{\text {st. }}: 98.0 \%\right.$;

$\left.24713^{\text {th. }}: 96.7 \%\right), 2.8 \%$ for $\mathrm{HNO}_{3}\left(1^{\text {st. }}: 97.9 \% ; 13^{\text {th. }}: 95.1 \%\right), 2.0 \%$ for $\mathrm{HNO}_{2}\left(1^{\text {st. }}: 97.9 \% ; 13^{\text {th: }}: 95.9 \%\right)$, and $2481.2 \%$ for $\mathrm{H}_{2} \mathrm{SO}_{4}\left(1^{\text {st: }}: 96.9 \% ; 13^{\text {th. }}: 95.7 \%\right)$, respectively. It may be due to the slight increasing pressure 249 drop which is to be discussed later. It is to be noted that the HWS was cleaned manually only once 250 every year by spraying water jet from the top of the modules during the test period (three cleaning 251 times in total, in July 2017, April 2018 and July 2019, respectively), which helped maintain $\geq 95 \%$ 252 high removal efficiency during this long-term test. In comparison, the packing materials of the 253 traditional packed tower need to be washed once every quarter to reduce particle clogging. After each 254 yearly maintenance denoted as " $M$ " in Fig. 2, the removal efficiency is increased slightly for HF ( 1 st $\left.255 \mathrm{M}:+1.4 \% ; 2^{\text {nd }} \mathrm{M}:+1.5 \%\right)$ and is not affected for other gases which all maintain to be very high. 
257 concentration, which is always higher than 95\% for all acidic gases when $\mathrm{C}_{\text {in }}$ varies from sub-ppmv

$258(709 \pm 324$ ppbv in average) to supper-ppmv $(105,505 \pm 41,039$ ppbv in average $)$ as shown in Fig. 3.

259 However, it is seen that the removal efficiencies of the HWS increase slightly by $3.5 \%, 2.2 \%$, and

$2601.5 \%$ when the inlet concentration increases by 8.2, 5.6, and 3.9 times for $\mathrm{HNO}_{3}, \mathrm{HCl}$, and $\mathrm{H}_{2} \mathrm{SO}_{4}$,

261 respectively as shown in Fig. 3a. The slightly positive correlation of the removal efficiency and the

inlet concentration of $\mathrm{HNO}_{3}$ and $\mathrm{HCl}$ was found with $\mathrm{R}^{2}$ of $0.37(\mathrm{p}$-value $=0.03<0.05)$ and $\mathrm{R}^{2}$ of 0.53

263 (p-value $=0.02<0.05)$, respectively. It is due to the variation of the inlet concentrations of $\mathrm{HNO}_{3}$ and

$264 \mathrm{HCl}$ from low $(<3,000 \mathrm{ppbv})$ to high concentrations $(>3,000 \mathrm{ppbv})$. In Fig. 3a, it is found that the

265 removal efficiency of $\mathrm{H}_{2} \mathrm{SO}_{4}$ is lower than those of $\mathrm{HNO}_{3}$ and $\mathrm{HCl}$ since the inlet concentration of

$266 \mathrm{H}_{2} \mathrm{SO}_{4}$ is lower than 1,600 ppbv and 9.2 times lower than $\mathrm{HNO}_{3}$ and 11.2 times lower than $\mathrm{HCl}$ in

267 average. In comparison, the inlet concentrations of $\mathrm{HF}$ and $\mathrm{CH}_{3} \mathrm{COOH}$ are always higher than 12,500

268 ppbv. Therefore, the removal efficiency also remains high and constant without an increasing trend, as

269 shown in Fig. 3b. The removal efficiency for $\mathrm{HNO}_{2}$ also shows no dependence on the inlet

270 concentration which also varies from low $(<3,000 \mathrm{ppbv})$ to high concentrations $(>3000$ ppbv) but

271 does not range widely $\left(\mathrm{C}_{\text {in-ave }}=2,899 \pm 1,596 \mathrm{ppbv}\right)$ as compared to that of $\mathrm{HCl}\left(\mathrm{C}_{\text {in-ave }}=8,493 \pm\right.$

$2723,566 \mathrm{ppbv})$ and $\mathrm{HNO}_{3}\left(\mathrm{C}_{\mathrm{in}-\mathrm{ave}}=6,969 \pm 3,353 \mathrm{ppbv}\right)$ with a wide concentration range (Fig. 3b). 
274 from 49.0 to $78.4 \mathrm{~Pa}\left(0.5\right.$ to $\left.0.8 \mathrm{cmH}_{2} \mathrm{O}\right)$, which is also close to the theoretical value of $59.8 \mathrm{~Pa}(0.58$

$275 \mathrm{cmH}_{2} \mathrm{O}$ ). The slight increase in the pressure drop during 3.5 years implies that only slight fouling of

276 the honeycomb material might have occurred which could not be cleaned thoroughly by water jet. In

277 Fig. 4a, it is found that the removal efficiency is decreased by $2.8 \%$ for $\mathrm{HNO}_{3}, 2.0 \%$ for $\mathrm{HNO}_{2}, 1.6 \%$

278 for $\mathrm{HF}$, and $1.2 \%$ for $\mathrm{H}_{2} \mathrm{SO}_{4}$ as the pressure drop is increased by $29.4 \mathrm{~Pa}\left(0.3 \mathrm{cmH}_{2} \mathrm{O}\right)$. The removal

279 efficiency shows a good negative correlation with the pressure drop for $\mathrm{HNO}_{3}\left(\mathrm{R}^{2}=0.88\right.$; $\mathrm{p}$-value $=$

$2800.02<0.05)$ with $95 \%$ confident interval and $\mathrm{H}_{2} \mathrm{SO}_{4}\left(\mathrm{R}^{2}=0.73\right.$; p-value $\left.=0.06<0.1\right), \mathrm{HF}\left(\mathrm{R}^{2}=0.70\right.$;

281 p-value $=0.08<0.1)$, and $\mathrm{HNO}_{2}\left(\mathrm{R}^{2}=0.67 ; \mathrm{p}\right.$-value $\left.=0.09<0.1\right)$ with $90 \%$ confident interval showing

282 a slight influence of the pressure drop on the removal efficiency for these gases. On the other hand,

283 the removal efficiency of $\mathrm{HCl}$ and $\mathrm{CH}_{3} \mathrm{COOH}$ does not show the dependence on the pressure drop as

284 shown in Fig. $4 \mathrm{~b}$ since $\mathrm{HCl}$ has high dissociation constant and $\mathrm{CH}_{3} \mathrm{COOH}$ has a very high inlet

285 concentration.

286 The lab-scale HWS operated at a flow rate of $1.0 \mathrm{CMM}$ and an $\mathrm{L} / \mathrm{G}$ ratio of $18 \mathrm{~L} \mathrm{~m}^{-3}$ in the 287 previous study [14] while the present scale-up, actual HWS device operated at a higher flow rate of $288100 \mathrm{CMM}$, a higher $\mathrm{L} / \mathrm{G}$ ratio of $26 \mathrm{~L} \mathrm{~m}^{-3}$, and the same retention time of $0.5 \mathrm{~s}$. Although the removal 289 efficiencies of $\mathrm{HF}, \mathrm{HCl}$, and $\mathrm{CH}_{3} \mathrm{COOH}$ for the present $\mathrm{HWS}$ are not as high as those in the previous 
290 study, which are about $99 \%$ for $\mathrm{HF}$ and $\mathrm{HCl}$ and nearly $100 \%$ for $\mathrm{CH}_{3} \mathrm{COOH}$, the long-term test results

291 show that the HWS always achieved removal efficiency higher than 95\% stipulated in the emission

292 standard [1]. The inlet concentrations in the previous study $\left(\mathrm{C}_{\mathrm{in}}=100-450 \mathrm{ppbv}\right.$ for HF, $3,000-11,000$

293 ppbv for $\mathrm{HCl}$, and 600-6500 ppbv for $\mathrm{CH}_{3} \mathrm{COOH}$ ) were lower than the current HWS. Since there are

29464 modules placed in parallel inside the HWS with some unused cross-section area (or dead space),

295 the required L/G ratio in the present study needs to be 1.4 times higher, which causes the pressure drop

296 to increase from 23.5 Pa to 49.0 Pa but it is still much lower than that of most traditional WSs.

297 The emission rates of each species in 12 sampling times were calculated from the outlet

298 concentrations and the air flow rate, and found to be less than $0.03,0.04,2.4 \times 10^{-3}, 4.0 \times 10^{-3}, 3.2 \times$

$29910^{-3}$, and $1.8 \times 10^{-3} \mathrm{~kg} \mathrm{~h}^{-1}$ for $\mathrm{HF}, \mathrm{CH}_{3} \mathrm{COOH}, \mathrm{HCl}, \mathrm{HNO}_{3}, \mathrm{HNO}_{2}$, and $\mathrm{H}_{2} \mathrm{SO}_{4}$, respectively. It indicates

300 that the exhausted gaseous acidic pollutants from the manufacturing process of the fab are well

301 controlled with only $2.5 \%, 3.0 \%, 0.3 \%, 0.4 \%, 0.2 \%$ and $0.6 \%$, respectively, of the total regulated mass

302 emission rates $\left(0.1 \mathrm{~kg} \mathrm{~h}^{-1}\right.$ for $\mathrm{H}_{2} \mathrm{SO}_{4}$ and $0.6 \mathrm{~kg} \mathrm{~h}^{-1}$ for other gases) for a semiconductor manufacturing

303 fab. In addition, the bad odor due to high $\mathrm{HF}$ and $\mathrm{CH}_{3} \mathrm{COOH}$ discharge concentrations disappears after

304 the installation of the present HWS.

\subsection{Results of theoretical prediction}

Fig. 5 shows the theoretical removal efficiencies of the HWS with the $\mathrm{D} \times \mathrm{Z}=0.3 \times 0.3 \mathrm{~m}$ for 
307 different acidic gases. It is seen that the $\mathrm{RE}_{\mathrm{GK}}$ is about $100 \%$ for all the acidic gases indicating that the 308 pollutants diffuse completely from the gas phase into the liquid phase fast enough without limiting the 309 ensuring dissociation and reaction processes of the pollutants in the water film. Whereas, the $\mathrm{RE}_{\mathrm{CA}}$ 310 based on $\mathrm{H}\left(\mathrm{RE}_{\mathrm{CA}-\mathrm{H}}\right)$ is $99.7 \%$ for $\mathrm{HF}, 98.0 \%$ for $\mathrm{CH}_{3} \mathrm{COOH}, 12.6 \%$ for $\mathrm{HCl}, 99 \%$ for $\mathrm{HNO}_{3}, 91.9 \%$

311 for $\mathrm{HNO}_{2}$, and $97.8 \%$ for $\mathrm{H}_{2} \mathrm{SO}_{4}$, respectively indicating that the mass transfer resistance across the 312 gas-liquid interface is high for $\mathrm{HCl}$, moderate for $\mathrm{HNO}_{2}$, and very low for other acidic gases. It is 313 because that the solubility of the $\mathrm{HCl}$ and $\mathrm{HNO}_{2}$ in the liquid is several orders of magnitude lower than 314 other acidic gases. The $\mathrm{RE}_{\mathrm{CA}}$ based on $\mathrm{H}^{*}\left(\mathrm{RE}_{\mathrm{CA}-\mathrm{H}^{*}}\right)$ of $\mathrm{HCl}$ and $\mathrm{HNO}_{2}$ is increased to $99.3 \%$ and 315 $99.2 \%$, respectively when $\mathrm{H}^{*}$ is used. This implies that the dissociation and reaction are the rate 316 limiting steps in the HWS and the chemical reaction enhances the absorption rate and increases the 317 dissolved capacity of the liquid film in the HWS. The $\mathrm{RE}_{\mathrm{CA}-\mathrm{H}^{*}}$ results are close to the experimental 318 data with less than $+3 \%$ biases.

To achieve the removal efficiency as high as the experimental data, the theoretical heights based 320 on $\mathrm{H}^{*}\left(\mathrm{Z}_{\mathrm{CA}-\mathrm{H}^{*}}\right)$ are $0.19 \mathrm{~m}$ for $\mathrm{HF}, 0.27 \mathrm{~m}$ for $\mathrm{CH}_{3} \mathrm{COOH}, 0.23 \mathrm{~m}$ for $\mathrm{HCl}, 0.25 \mathrm{~m}$ for $\mathrm{HNO}_{3}, 0.21 \mathrm{~m}$ 321 for $\mathrm{HNO}_{2}$, and $0.16 \mathrm{~m}$ for $\mathrm{H}_{2} \mathrm{SO}_{4}$, respectively, as shown in Fig. S2 in the SI. It indicates that the 322 theoretical values are very similar to the designed value of $0.3 \mathrm{~m}$ for mixed acidic gas control. The 323 theoretical heights based on $\mathrm{H}\left(\mathrm{Z}_{\mathrm{CA}-\mathrm{H}}\right)$ are also shown in Fig. $\mathrm{S} 2$ in the SI, which demonstrate that it is 
324 required longer module to achieve the removal efficiency $\geq 95 \%$ for $\mathrm{HCl}\left(\mathrm{Z}_{\mathrm{CA}-\mathrm{H}}=8.5 \mathrm{~m}\right)$ and $\mathrm{HNO}_{2}$

$325\left(\mathrm{Z}_{\mathrm{CA}-\mathrm{H}}=0.4 \mathrm{~m}\right)$ when the scrubbing $\mathrm{NaOH}$ solution is not added. In summary, the equations based on

326 the two-film theory can be used to predict the theoretical removal efficiency of the HWS and

327 theoretical height of the honeycomb module with good accuracy.

Fig. 6 shows the theoretical removal efficiency $\left(\mathrm{RE}_{\mathrm{CA}-\mathrm{H}^{*}}\right)$ and the theoretical height $\left(\mathrm{Z}_{\mathrm{CA}-\mathrm{H}^{*}}\right)$ of

329 the WS packed with the traditional packing materials including raschig rings $\left(D_{e}=6,13\right.$, and $\left.25 \mathrm{~mm}\right)$

330 and berl saddle $\left(D_{\mathrm{e}}=25 \mathrm{~mm}\right)$. As compared with the honeycomb module with the similar specific

331 surface area, theoretical removal efficiencies of the WS packed with 13-mm raschig ring are high for

$332 \mathrm{HF}, \mathrm{HCl}$ and $\mathrm{H}_{2} \mathrm{SO}_{4}\left(\mathrm{RE}_{\mathrm{CA}-\mathrm{H}^{*}} \geq 99.9 \%\right)$ but low for $\mathrm{CH}_{3} \mathrm{COOH}\left(\mathrm{RE}_{\mathrm{CA}-\mathrm{H}^{*}}=62.3 \%\right)$ and $\mathrm{HNO}_{2}\left(\mathrm{RE}_{\mathrm{CA}-}\right.$

$\left.333 \mathrm{H}^{*}=17.2 \%\right)$. It is because $\mathrm{CH}_{3} \mathrm{COOH}$ has the lowest dissociation constant among these acidic gases

334 and both Henry's law and dissociation constants of $\mathrm{HNO}_{2}$ are several orders of magnitude lower than

335 other acidic gases. When the 6-mm raschig ring with a higher specific surface area than the honeycomb

336 module is used, the removal efficiencies can be achieved $95 \%$ for $\mathrm{CH}_{3} \mathrm{COOH}$ and $52.6 \%$ for $\mathrm{HNO}_{2}$,

337 respectively. However, the removal efficiencies of the traditional WS packed with 6-mm rachig rings

338 are still lower than those of the $\mathrm{HWS}$ for $\mathrm{CH}_{3} \mathrm{COOH}\left(\mathrm{Z}_{\mathrm{CA}-\mathrm{H}^{*}}=98.1 \%\right)$ and $\mathrm{HNO}_{2}\left(\mathrm{Z}_{\mathrm{CA}-\mathrm{H}^{*}}=99.2 \%\right)$. It

339 implies that $\mathrm{HWS}$ enhances the mass transfer rate of $\mathrm{CH}_{3} \mathrm{COOH}$ and $\mathrm{HNO}_{2}$ which have low solubility

340 and dissociation ability due to its multiple small gaps with uniform water-absorbing surface. 
341 Additionally, the theoretical pressure drop of the WS packed with the 6-mm and 13-mm raschig rings

342 are about $490 \mathrm{~Pa}\left(5.0 \mathrm{cmH}_{2} \mathrm{O}\right)$ and $245 \mathrm{~Pa}\left(2.5 \mathrm{cmH}_{2} \mathrm{O}\right)$, respectively, which are much higher than that

343 of the HWS (59.8 Pa or $0.58 \mathrm{cmH}_{2} \mathrm{O}$ ). The theoretical heights of the WS packed with the 6-mm and

$34413-\mathrm{mm}$ raschig rings need to be as large as $1.34 \mathrm{~m}$ and $5.3 \mathrm{~m}$, respectively to achieve the removal

345 efficiency higher than $95 \%$ for all the acidic gases for mixed gas control as shown in Fig. $6 \mathrm{~b}$. That is,

346 the HWS is an economical control device for mixed gas control as compared with the traditional WS.

347 To reduce the pressure drop, the WS is usually packed with bigger packing materials with lower

348 specific surface areas such as $25-\mathrm{mm}$ raschig ring or $25-\mathrm{mm}$ berl saddle. However, the removal

349 efficiency of the traditional WS packed with $25-\mathrm{mm}$ perl saddle is not only as low as $29.1 \%$ for

$350 \mathrm{CH}_{3} \mathrm{COOH}$ and $6.42 \%$ for $\mathrm{HNO}_{2}$ but just $92 \%$ for $\mathrm{H}_{2} \mathrm{SO}_{4}$, which does not meet the removal efficiency

351 requirement. It is because that the inlet concentrations of $\mathrm{H}_{2} \mathrm{SO}_{4}$ are very low $\left(\mathrm{C}_{\mathrm{in}}=0.24-1.58 \mathrm{ppmv}\right)$

352 as compared to those of the acidic gases. Although the removal efficiency of the WS packed with 25-

$353 \mathrm{~mm}$ raschig ring is also as high as $95.3 \%$ for $\mathrm{H}_{2} \mathrm{SO}_{4}$, it is still lower than that of the HWS and the WS

354 packed with 6-mm and $13-\mathrm{mm}$ raschig rings, which is due to its lower specific surface area. This

355 indicates that the HWS outperforms the traditional WS with the similar or even larger specific surface

356 areas for the removal efficiency of the mixed gas and pressure drop.

357 4. Conclusion 
359 gaseous acidic gases and odor at a semiconductor manufacturing fab in 3.5 years from August 2016 to

360 March 2020. The results of 12 removal efficiency tests indicated that the HWS is capable of removing

361 the gaseous acidic gases and odor with the inlet concentrations varying from low concentrations of

$364 \mathrm{CH}_{3} \mathrm{COOH}$ and 31,874-180,685 ppbv for HF. All removal efficiency data, which are 95.6\%-98.3\%

365 for $\mathrm{HF}, 95.0 \%-98.3 \%$ for $\mathrm{CH}_{3} \mathrm{COOH}, 96.1 \%-98.5 \%$ for $\mathrm{HCl}, 95.1 \%-98.8 \%$ for $\mathrm{HNO}_{3}, 95.0 \%-97.9 \%$

366 for $\mathrm{HNO}_{2}$, and $95.2 \%-97.6$ for $\mathrm{H}_{2} \mathrm{SO}_{4}$, respectively, met the regulation for the control devices in

367 Taiwan. The pressure drop of the HWS maintained as low as 49.0-78.4 $\mathrm{Pa}\left(0.5-0.8 \mathrm{cmH}_{2} \mathrm{O}\right)$ and 368 increased only slightly during the 3.5-yr period, which is much lower than that of the traditional WSs.

369 The theoretical removal efficiency and the theoretical height of the HWS module were close to the 370 experimental data indicating that the theoretical equations can facilitate the design of the HWS. The

371 HWS showed higher theoretical removal efficiency and lower theoretical height for the mixed gas 372 control, especially for the acidic gases with low solubility and dissociation ability as compared with 373 the WS packed with the traditional packing materials. That is, the honeycomb wet scrubber can be 374 used as an efficient device for mixed acidic gas and odor control with high removal efficiency and low 
375 pressure drop for the long-term.

\section{$376 \quad$ Declarations}

\section{Acknowledgments}

378 The authors gratefully acknowledge financial support from the Taiwan Ministry of Science and

379 Technology via the contracts MOST 109-2622-8-009-017-TE5 and 107-2221-E-009-004-MY3 and 380 the Higher Education Sprout Project of the National Chiao Tung University and Ministry of Education 381 (MOE), Taiwan.

\section{Authors' contributions}

383 YLL and BTW designed the study and carried out the field tests. GYL and ZL contributed to data 384 analysis. GHH drafted and edited the manuscript. LTC contributed to data analysis, modeling, and 385 manuscript preparation. DYHP and CJT critically reviewed and edited the final manuscript. All the 386 authors read and approved the final manuscript.

\section{$387 \quad$ Funding}

388 This research did not receive any specific grant from funding agencies in the public, commercial, or 389 not-for-profit sectors.

\section{Availability of data and materials}

391 All data generated or analyzed during this study are included in this article and its supplementary 
392 information file. The raw data are available from the corresponding author upon reasonable request.

\section{Competing interests}

394 The authors declare they have no competing interests.

\section{Nomenclature}
$a_{t} \quad$ Specific surface area $\left(\mathrm{m}^{2} \mathrm{~m}^{-3}\right)$
$\mathrm{N}_{\mathrm{RE}} \quad$ Reynolds number
$\mathrm{C}_{\text {in }} \quad$ Inlet concentration (ppbv)
$\mathrm{N}_{\mathrm{Sc}} \quad$ Schmidt number
$\mathrm{C}_{\text {out }} \quad$ Outlet concentration (ppbv)
Q Airflow rate $\left(\mathrm{m}^{3} \mathrm{~s}^{-1}\right)$
$\mathrm{C}_{\mathrm{w}, \text { in }}$ Inlet concentration of the gaseous
Gas constant $\left(\mathrm{m}^{3} \mathrm{~Pa} \mathrm{~K}^{-1} \mathrm{~mole}^{-1}\right)$
pollutant in the liquid phase (ppbv)
$\mathrm{C}_{\mathrm{w}, \text { out }}$
Out concentration of the gaseous RE
Experimental removal efficiency (\%) pollutant in the liquid phase (ppbv)
$\mathrm{D}$ The inner diameter of the packing $\mathrm{RE}_{\mathrm{CA}}$ Theoretical removal efficiency based on material (m) two film theory $(\%)$
$D_{e} \quad$ The equivalent diameter of the raschig $R_{G K}$ Theoretical removal efficiency based on ring $(\mathrm{m})$ diffusion theory $(\%)$
$D_{g} \quad$ Gas-phase diffusion coefficient $\left(\mathrm{m}^{2} \mathrm{~s}^{-1}\right) \quad \mathrm{S} \quad$ Empty cross-section surface area $\left(\mathrm{m}^{2}\right)$
$\mathrm{D}_{\mathrm{w}} \quad$ Liquid-phase diffusion coefficient $\left(\mathrm{m}^{2} \mathrm{~s}^{-} \mathrm{T} \quad\right.$ Temperature (K)
$\left.{ }^{1}\right)$
g Gravity acceleration $\left(\mathrm{m} \mathrm{s}^{-2}\right)$
$\mathrm{U}_{\mathrm{t}} \quad$ Superficial air velocity $\left(\mathrm{m} \mathrm{s}^{-1}\right)$
$\mathrm{G}_{\mathrm{g}} \quad$ The mass flow rate of the air $\left(\mathrm{kg} \mathrm{s}^{-1} \mathrm{~m}^{-2}\right) \quad \mathrm{V}_{\mathrm{m}}$ The molar flow rate of the air $\left(\right.$ mole s$\left.^{-1}\right)$ 
$\mathrm{G}_{\mathrm{w}} \quad$ Mass flow rate of the liquid $\left(\mathrm{kg} \mathrm{s}^{-1} \mathrm{~m}^{-2}\right) \quad \mathrm{W} \quad$ Gap distance of the honeycomb module ( $\left.\mathrm{m}\right)$

$\mathrm{G}_{\mathrm{my}} \quad$ The molar flux of the air $\left(\mathrm{mole} \mathrm{s}^{-1} \mathrm{~m}^{-2}\right) \quad \mathrm{W}$, The equivalent diameter of the honeycomb module (m)

$\mathrm{H} \quad$ Henry's low constant $\left(\operatorname{atm~M}^{-1}\right) \quad \mathrm{Z} \quad$ Height of the honeycomb module (m)

$\mathrm{H}^{*} \quad$ Effective Henry's low constant (atm $\mathrm{M}^{-} \quad € \quad$ Fractional voids in dry packing $\left.{ }^{1}\right)$

$\mathrm{K} \quad$ Dissociation constant $\left(\mathrm{M} \mathrm{atm}^{-1}\right) \quad \rho_{\mathrm{g}} \quad$ Air density $\left(\mathrm{kg} \mathrm{m}^{-3}\right)$

$\mathrm{K}_{\mathrm{g}} \quad$ Overall mass transfer coefficient (mole $\mathrm{s}^{-} \rho_{\mathrm{w}} \quad$ Liquid density $\left(\mathrm{kg} \mathrm{m}^{-3}\right)$ $\left.{ }^{1} \mathrm{~m}^{-2}\right)$

$\mathrm{kg} \quad$ Gas phase mass transfer coefficient $\mu_{\mathrm{g}} \quad$ Air viscosity $\left(\mathrm{kg} \mathrm{s} \mathrm{m}^{-1}\right)$ $\left(\right.$ mole s $\left.^{-1} \mathrm{~m}^{-2}\right)$

$\mathrm{kw} \quad$ Liquid phase mass transfer coefficient $\mu_{\mathrm{w}} \quad$ Liquid viscosity $\left(\mathrm{kg} \mathrm{s} \mathrm{m}^{-1}\right)$ $\left(\right.$ mole s$\left.^{-1} \mathrm{~m}^{-2}\right)$

L The total length of the PP fabric plate (m) $\quad \xi \quad$ Dimensionless parameter

$\mathrm{L}_{\mathrm{m}} \quad$ Liquid molar flow rate $\left(\right.$ mole s $\left.^{-1}\right) \quad \Gamma \quad$ Liquid mass flow rate based on the wetted perimeter $\left(\mathrm{kg} \mathrm{s}^{-1} \mathrm{~m}^{-1}\right)$

\section{References}

397 1. TWEPA. Air pollution control and emissions standards for the semiconductor industry. 2002.

398 https://law.moj.gov.tw/ENG/LawClass/LawAll.aspx?pcode=O0020032. Accessed 06 Jan 2021.

399 2. TWEPA. Optoelectronic material and element manufacturing industry air pollution control and

400 emission standards. 2006. https://law.moj.gov.tw/ENG/LawClass/LawAll.aspx?pcode=O0020073. 
$401 \quad$ Accessed 06 Jan 2021.

402 3. Chein H, Chen TM, Aggarwal SG, Tsai CJ, Huang CC. Inorganic acid emission factors of 403 semiconductor manufacturing processes. J Air Waste Manag Assoc. 2004;54:218-28.

404 4. Huang CH, Ho YT, Tsai CJ. Measurement of inorganic acidic gases and particles from the stack 405 of semiconductor and optoelectronic industries. Sep Purif Technol. 2005;39:2223-34.

406 5. Eom YS, Hong JH, Lee SJ, Lee EJ, Cha JS, Lee DG, et al. Emission factors of air toxics from 407 semiconductor manufacturing in Korea. J Air Waste Manag Assoc. 2006;56:1518-24.

408 6. USEPA. Hazardous air pollutants. 2003. http:/www.epa.gov/ttn/atw/. Accessed 06 Jan 2021.

409 7. Le TC, Wang YC, Pui DY, Tsai CJ. Characterization of atmospheric $\mathrm{PM}_{2.5}$ inorganic aerosols using 410 the semi-continuous PPWD-PILS-IC system and the ISORROPIA-II. Atmos. 2020;11:820.

8. WHO. Health

effects

of

particulate

matter.

2013.

412 https://www.euro.who.int/_ data/assets/pdf_file/0006/189051/Health-effects-of-particulate-

413 matter-final-Eng.pdf. Accessed 06 Jan 2021.

414 9. Tsai CJ, Chang CT, Liu TW, Huang CC, Chien CL, Chein HM. Emission characteristics and 415 control efficiency of acidic and basic gases and aerosols from packed towers. Atmos Environ. 2004;38:643-6.

10. Chein HM, Aggarwal SG, Wu HH, Chen TM, Huang CC. Field enhancements of packed-bed 
418 performance for low-concentration acidic and basic-waste gases from semiconductor 419 manufacturing process. J Air Waste Manag Assoc. 2005;55:647-57.

420 11. Chien CL, Tsai CJ, Sheu SR, Cheng YH, Starik AM. High-efficiency parallel-plate wet scrubber

421 (PPWS) for soluble gas removal. Sep Purif Technol. 2015;142:189-95.

422 12. Bandyopadhyay A. Selecting particulate and gaseous pollution control device. Particul Sci Technol. $423 \quad 2012 ; 30: 238-86$.

424 13. Jafari MJ, Ghasemi R, Mehrabi Y, Yazdanbakhsh RA, Hajibabaei M. Influence of liquid and gas 425 flow rates on sulfuric acid mist removal from air by packed bed tower. Iran J Environ Healt Sci $426 \quad$ Eng. 2012;9:20.

427 14. Chien CL, Iswara AP, Liou YL, Wang BT, Chang JC, Hung YH, et al. A real-time monitoring 428 packed towers. Sep Purif Technol. 2015;154:137-48.

430

431

15. Kurella S, Balla M, Bhukya PK. Scrubbing of $\mathrm{HCl}$ gas from synthesis gas in a multistage dualflow sieve plate wet scrubber by alkaline solution. J Chem Eng Proc Technol. 2015;06.

432 16. Jafari MJ, Matin AH, Rahmati A, Azari MR, Omidi L, Hosseini SS, et al. Experimental 433 optimization of a spray tower for ammonia removal. Atmos Pollut Res. 2018;9:783-90.

434 17. Lee M, Kim HH, Koo J. Quantitative analysis of the impact of inlet duct spray on scrubbing 
efficiency using experimental design. J ILASS-Korea. 2019;24:8-14 [In Korean].

436 18. Cooper CD, Alley FC. Air pollution control: A design approach. USA: Waveland press Inc.; 2010.

437 19. Nisola GM, Valdehuesa KNG, Anonas AV, Ramos KRM, Lee WK, Chung WJ. Performance

438 evaluation of poly-urethane foam packed-bed chemical scrubber for the oxidative absorption of

$439 \mathrm{NH}_{3}$ and $\mathrm{H}_{2} \mathrm{~S}$ gases. J Environ Sci Health A Tox Hazard Subst Environ Eng. 2018;53:25-32.

440 20. Wang LK, Taricska JR, Hung Y-T, Eldridge JE, Li KH. Wet and dry scrubbing. In: Wang LK,

441 Pereira NC, Hung YT, editors. Air Pollution Control Engineering. Totowa, NJ: Humana Press;

$442 \quad$ 2004, p. 197-305.

443 21. Han BW, Kim HJ, Kim YJ, Han KS. Removal characteristics of gaseous contaminants by a wet

444 scrubber with different packing materials. J Korean Soc Atmos Environ. 2007;23:744-51 [In

$445 \quad$ Korean].

446 22. Kim HJ, Han B, Kim YJ, Yoa SJ, Oda T. Integration of a nonmetallic electrostatic precipitator and

447 a wet scrubber for improved removal of particles and corrosive gas cleaning in semiconductor

448 manufacturing industries. J Air Waste Manage. 2012;62:905-15.

449 23. USEPA. Air pollution control cost manual. 2002. https://www3.epa.gov/ttncatc1/dir1/c_allchs.pdf.

$450 \quad$ Accessed 01 Jan 2021.

451 24. Perry RH, Green DW. Perry’s chemical engineers' handbook New York: McGraw-Hill Inc.; 2007. 
452 25. Dal Pozzo A, Guglielmi D, Antonioni G, Tugnoli A. Environmental and economic performance 453 assessment of alternative acid gas removal technologies for waste-to-energy plants. Sustain Prod 454 Consump. 2018;16:202-15.

455 26. Chien $\mathrm{TW}$, Chu $\mathrm{H}$. Removal of $\mathrm{SO}_{2}$ and $\mathrm{NO}$ from flue gas by wet scrubbing using an aqueous 456 $\mathrm{NaClO}_{2}$ solution. J Hazard Mater. 2000;80:43-57.

457 27. Zhang L, Wu S, Gao Y, Sun B, Luo Y, Zou H, et al. Absorption of $\mathrm{SO}_{2}$ with calcium-based solution 458 in a rotating packed bed. Sep Purif Technol. 2019;214:148-55.

459 28. Pillai $\mathrm{KC}$, Chung SJ, Raju T, Moon I-S. Experimental aspects of combined $\mathrm{NO}_{\mathrm{x}}$ and $\mathrm{SO}_{2}$ removal 460 from flue-gas mixture in an integrated wet scrubber-electrochemical cell system. Chemosphere. 2009;76:657-64.

462

29. Jafari M, Hajibabaei M, Yazdanbakhsh A, Mehrabi Y, Ghasemi R, Kazempour M. The role of 463 packing media in a scrubber performance removing sulfuric acid mists. Int $\mathrm{J}$ Occup Hyg. 2012;4:26-31.

465

30. Tsai CJ, Huang CH, Wang SH, Shih TS. Design and testing of a personal porous-metal denuder. Aerosol Sci Technol. 2001;35:611-6. acidic and basic gases. Environ Sci Technol. 2001;35:2572-5. 
469 32. Tsai CJ, Huang CH, Lin YC, Shih TS, Shih BH. Field test of a porous-metal denuder sampler. $470 \quad$ Aerosol Sci Technol. 2003;37:967-74.

471 33. Hinds WC. Aerosol technology: properties, behavior, and measurement of airborne particles. LA:

$472 \quad$ John Wiley \& Sons; 1999.

473 34. Gormley PG, Kennedy M. Diffusion from a stream flowing through a cylindrical tube. Math Proc $474 \quad$ R Ir Acad. 1948;52:163-9.

475 35. Bennett CO, Myers JE. Momentum, heat, and mass transfer. New York: McGraw-Hill Inc.; 1982.

476 36. Fair JR, Steinmeyer DE, Penney WR, Crocker BB. Gas absorption and gas-liquid system design.

477 In: Perry RH, Green D, editors. Perry's Chemical Engineering Handbook. New York, USA:

$478 \quad$ McGraw-Hill Inc.; 2001.

479 37. Cussler EL. Diffusion: mass transfer in fluid systems. 4th ed. United Kingdom: Cambridge $480 \quad$ University Press; 2009.

481 38. Seinfeld JH, Pandis SN. Atmospheric chemistry and physics: from air pollution to climate change.

$482 \quad$ LA: John Wiley \& Sons; 2016.

483 39. Sander R. Compilation of Henry's law constants (version 4.0) for water as solvent. Atmos Chem

$484 \quad$ Phys. 2015;15:4399-981. 
486 Table 1 Operating parameters of the HWS at a semiconductor fab and the design criteria of TWEPA.

\begin{tabular}{lccc}
\hline Operating parameter & Value & Criteria & Unit \\
\hline${ }^{\text {a} W e t t i n g ~ f a c t o r ~}$ & 0.1 & $\geq 0.1$ & $\mathrm{~m}^{2} \mathrm{~h}^{-1}$ \\
Retention time & 0.5 & $\geq 0.5$ & $\mathrm{sec}$ \\
Pressure drop & $49 \sim 78.4$ & - & $\mathrm{Pa}$ \\
Airflow rate & 100 & - & $\mathrm{m}^{3} \mathrm{~min}^{-1}$ \\
Liquid flow rate & 2,600 & - & $\mathrm{L} \mathrm{min}^{-1}$ \\
pH & $7.5 \sim 9.0$ & $\geq 7$ & - \\
Packing material & 483 & $\geq 90$ & $\mathrm{~m}^{2} \mathrm{~m}^{-3}$ \\
\hline
\end{tabular}

487 a Wetting factor $=$ scrubbing water flow rate divided by (the specific surface area of the packing materials times the 488 horizontal cross-sectional area of the tower).

489

490

491

492

493

494

495

496

497

498

499 
500 Table 2 Some typical packing materials.

\begin{tabular}{|c|c|c|c|c|c|c|}
\hline $\begin{array}{l}\text { Packing } \\
\text { materials }\end{array}$ & $\begin{array}{c}{ }^{a} \mathbf{D} \times \mathbf{Z} \text { or } \\
\mathbf{L} \times \mathbf{W}_{\mathrm{T}} \times \mathbf{Z} \\
(\mathbf{c m})\end{array}$ & $\begin{array}{c}\text { Bulk } \\
\text { density } \\
\left(\mathrm{kg} \mathrm{m}^{-3}\right)\end{array}$ & $\begin{array}{c}\text { Specific } \\
\text { surface area } \\
\left(\mathrm{m}^{2} \mathrm{~m}^{-3}\right)\end{array}$ & $\begin{array}{c}\mathrm{L} / \mathrm{G} \text { ratio } \\
\left(\mathrm{L} \mathrm{m}^{-3}\right)\end{array}$ & $\begin{array}{l}\text { Pressure } \\
\text { drop (Pa) }\end{array}$ & Reference \\
\hline Honeycomb & $30 * 30$ & 160 & 483 & 26 & ${ }^{b} 59.8$ & Present \\
\hline Honeycomb & $30 * 30$ & 160 & 483 & 18.5 & 23.5 & [14] \\
\hline MPPM & $30 * 30 * 30$ & 920 & 327 & 18.5 & 23.5 & [11] \\
\hline $\begin{array}{l}\text { Polypropylene } \\
\text { ball }(2.5 \mathrm{~cm})\end{array}$ & $47 * 40 * 40$ & 139 & 379 & $1.5-3$ & $<196$ & [21] \\
\hline $\begin{array}{l}\text { Ceramic intalox } \\
\text { saddle }(2.5 \mathrm{~cm})\end{array}$ & $30 * 61$ & 610 & 250 & $1.4-2.1$ & $265-1932$ & [29] \\
\hline $\begin{array}{l}\text { Raschig ring (1.3 } \\
\quad \mathrm{cm})\end{array}$ & $30 * 61$ & - & 350 & $1.4-2.1$ & 294-1058 & [29] \\
\hline $\begin{array}{l}\text { Polyethylene knit } \\
\text { packing }\end{array}$ & $14 * 10$ & - & 150 & 3.0 & $\sim 2000$ & [27] \\
\hline $\begin{array}{l}\text { SS wire mesh } \\
\text { packing }\end{array}$ & $14^{*} 10$ & - & 500 & 3.0 & $\sim 2000$ & [27] \\
\hline
\end{tabular}

501

${ }^{a}$ Packing dimensions: diameter $\times$ height $(\mathrm{D} \times \mathrm{Z})$ or length $\times$ width $\times$ height $\left(\mathrm{L}^{\mathrm{a}} \times \mathrm{W}_{\mathrm{T}} \times \mathrm{Z}\right){ }^{\mathrm{b}}$ Theoretical value

502

503

504

505

506

507

508 


\section{$509 \quad$ Figure captions}

510 Fig. 1 a Experimental setup of the HWS at a semiconductor fab, and b pictorial view of honeycomb 511 packing installed in the HWS.

512 Fig. 2 Removal efficiency versus test date for a $\mathrm{HF}$ and $\mathrm{CH}_{3} \mathrm{COOH}, \mathbf{b} \mathrm{HCl}$ and $\mathrm{HNO}_{3}$, and $\mathbf{c} \mathrm{HNO}_{2}$ 513 and $\mathrm{H}_{2} \mathrm{SO}_{4}$ (Note: (M): maintenance day).

514 Fig. 3 Removal efficiency versus inlet concentration for a $\mathrm{HCl}, \mathrm{HNO}_{3}$, and $\mathrm{H}_{2} \mathrm{SO}_{4}$, and b $\mathrm{HF}$, $515 \mathrm{CH}_{3} \mathrm{COOH}$, and $\mathrm{HNO}_{2}$.

516 Fig. 4 Removal efficiency versus pressure drop for a $\mathrm{HF}, \mathrm{HNO}_{2}, \mathrm{HNO}_{3}$, and $\mathrm{H}_{2} \mathrm{SO}_{4}$, and $\mathbf{b} \mathrm{HCl}$ and $517 \mathrm{CH}_{3} \mathrm{COOH}$.

518 Fig. 5 Comparison of the experimental and theoretical removal efficiencies for different acidic gases 519 (Note: the data are slightly shifted to avoid overlapping).

520 Fig. 6 Comparison of $\mathbf{a}$ the theoretical removal efficiency, and $\mathbf{b}$ the theoretical height of the traditional

521 WS and the HWS (Note: the data are slightly shifted to avoid overlapping).

522

523

524

525 


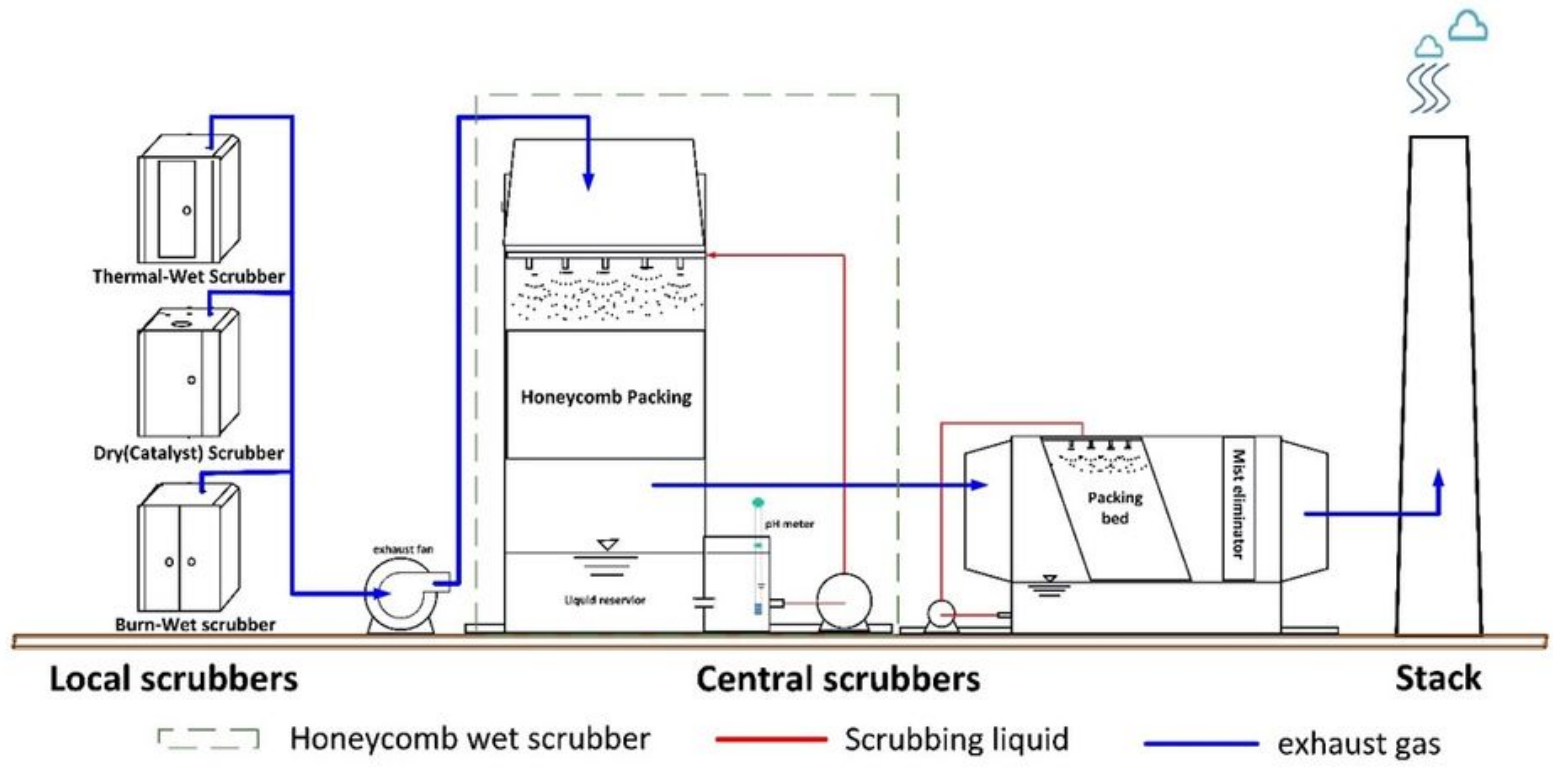

(a)

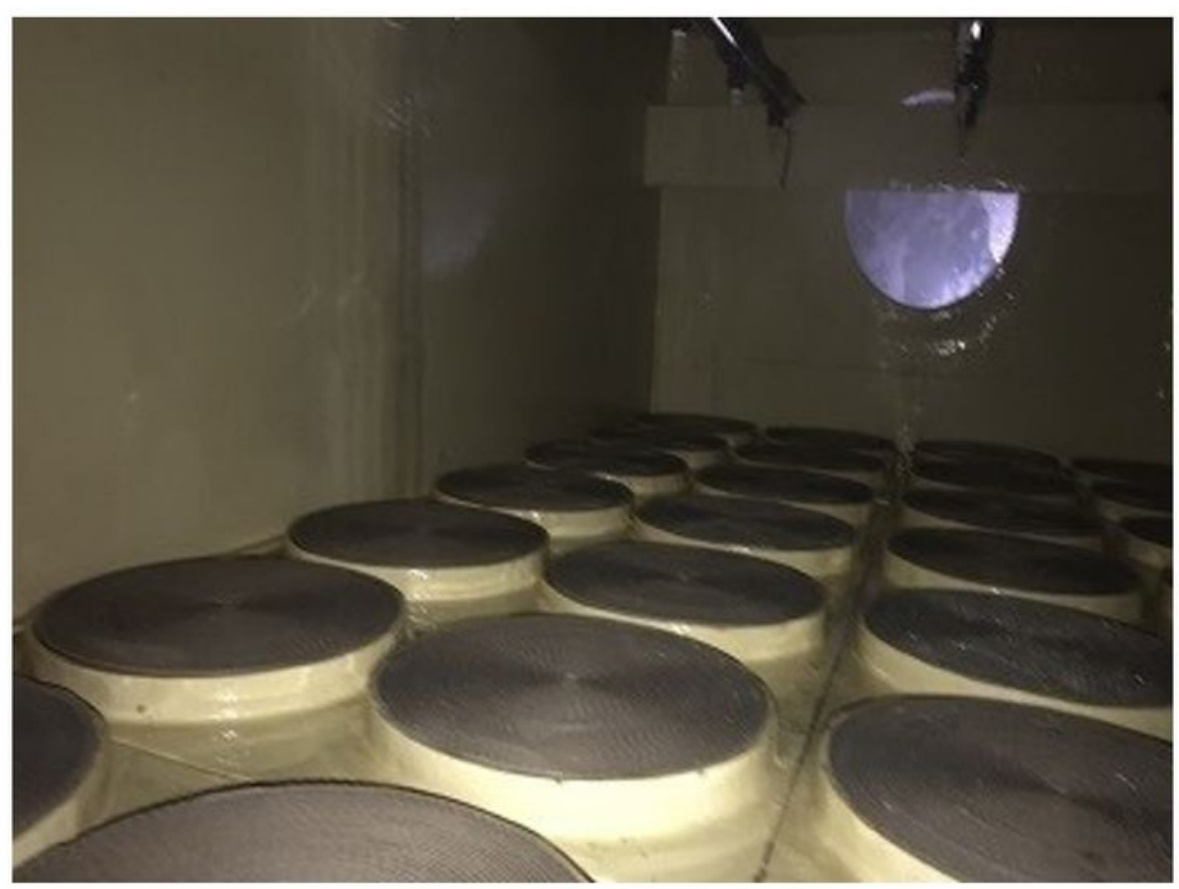

(b)

\section{Figure 1}

a Experimental setup of the HWS at a semiconductor fab, and b pictorial view of honeycomb packing installed in the HWS. 

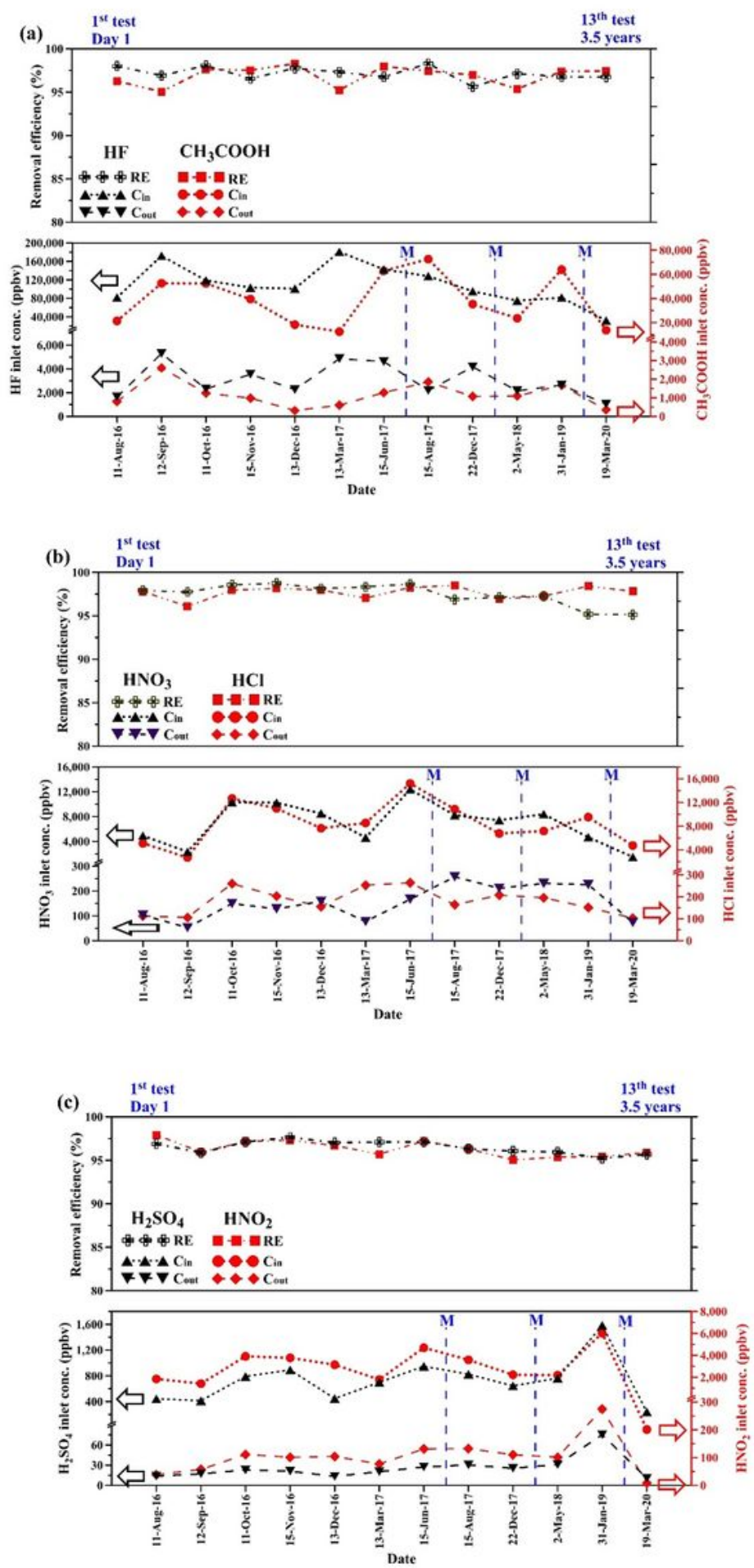

\section{Figure 2}

Removal efficiency versus test date for a $\mathrm{HF}$ and $\mathrm{CH} 3 \mathrm{COOH}, \mathrm{b} \mathrm{HCl}$ and $\mathrm{HNO} 3$, and c $\mathrm{HNO} 2$ and $\mathrm{H} 2 \mathrm{SO} 4$ (Note: (M): maintenance day). 

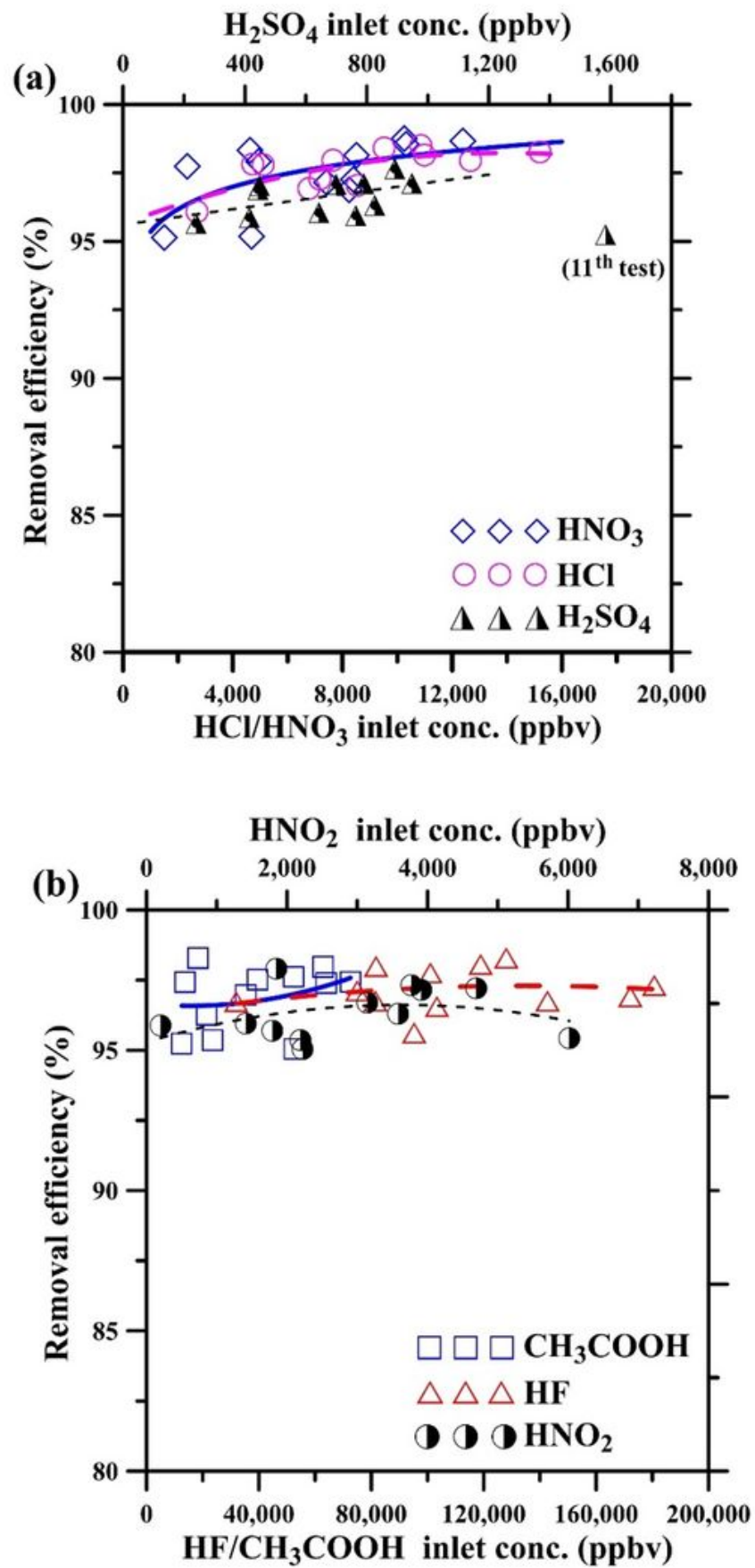

Figure 3

Removal efficiency versus inlet concentration for a $\mathrm{HCl}, \mathrm{HNO} 3$, and $\mathrm{H} 2 \mathrm{SO}$, and b $\mathrm{HF}, \mathrm{CH} 3 \mathrm{COOH}$, and HNO2. 

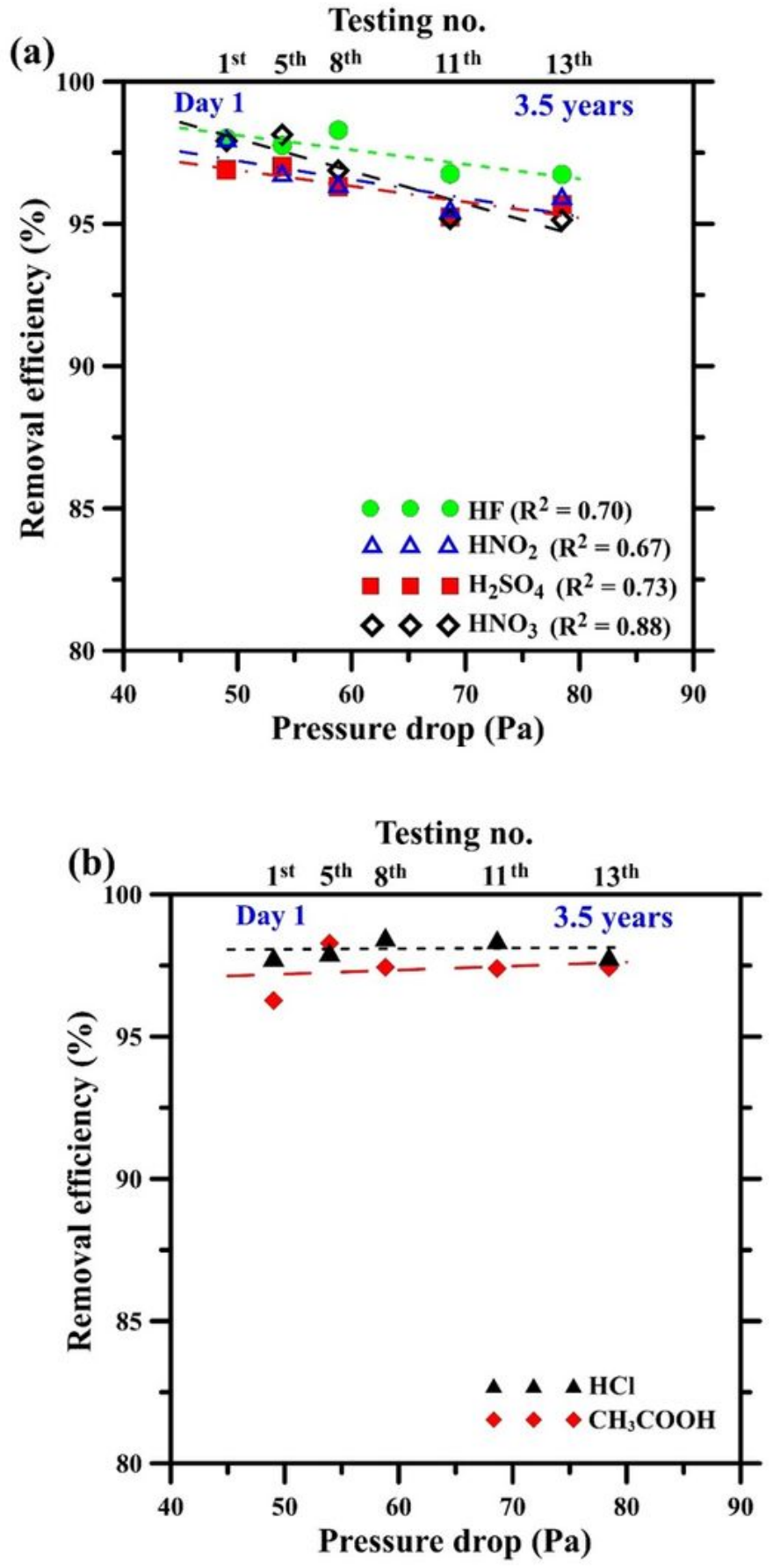

Figure 4

Removal efficiency versus pressure drop for a $\mathrm{HF}, \mathrm{HNO} 2, \mathrm{HNO} 3$, and $\mathrm{H} 2 \mathrm{SO} 4$, and b $\mathrm{HCl}$ and $\mathrm{CH} 3 \mathrm{COOH}$. 


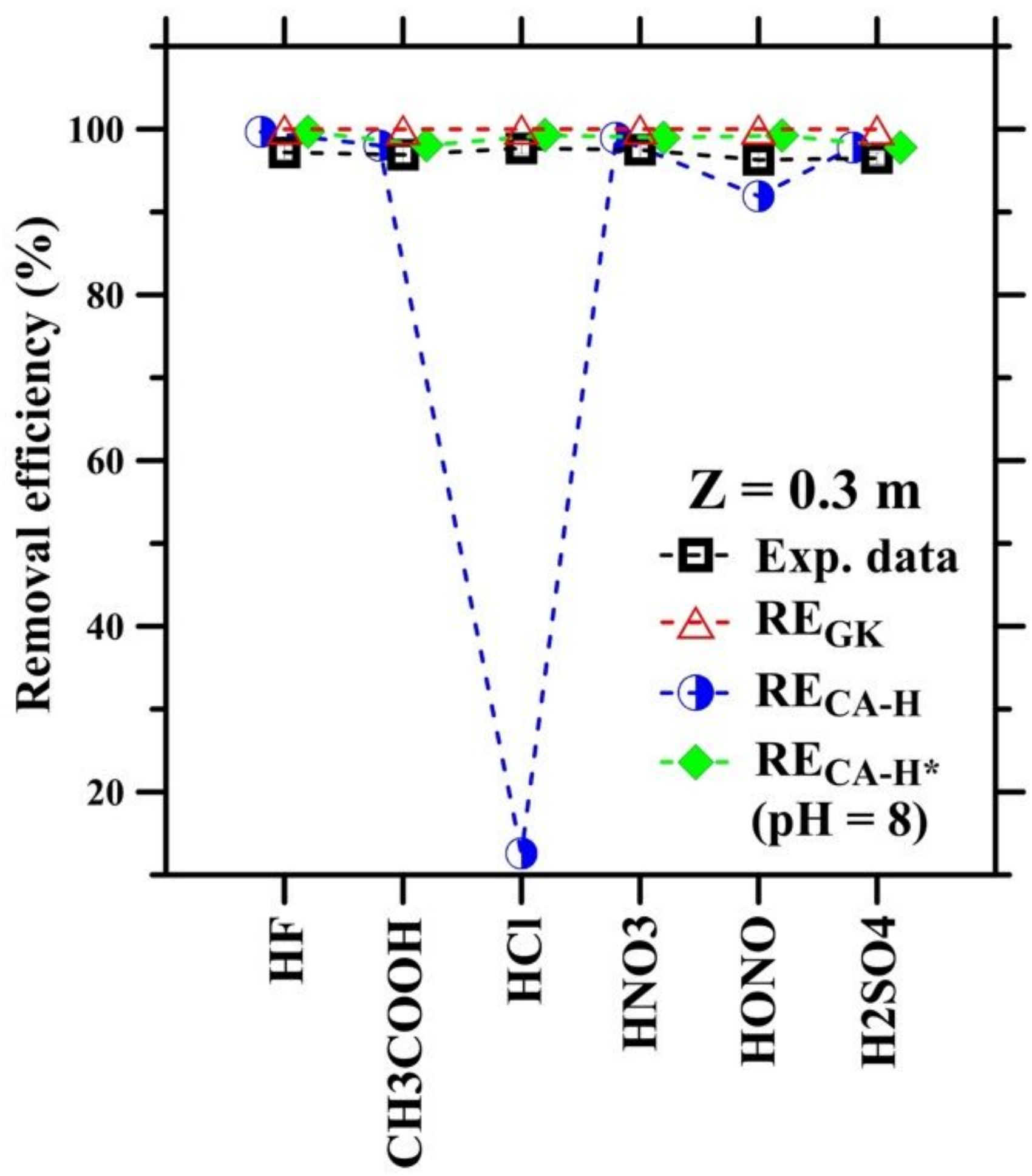

Figure 5

Comparison of the experimental and theoretical removal efficiencies for different acidic gases (Note: the data are slightly shifted to avoid overlapping). 

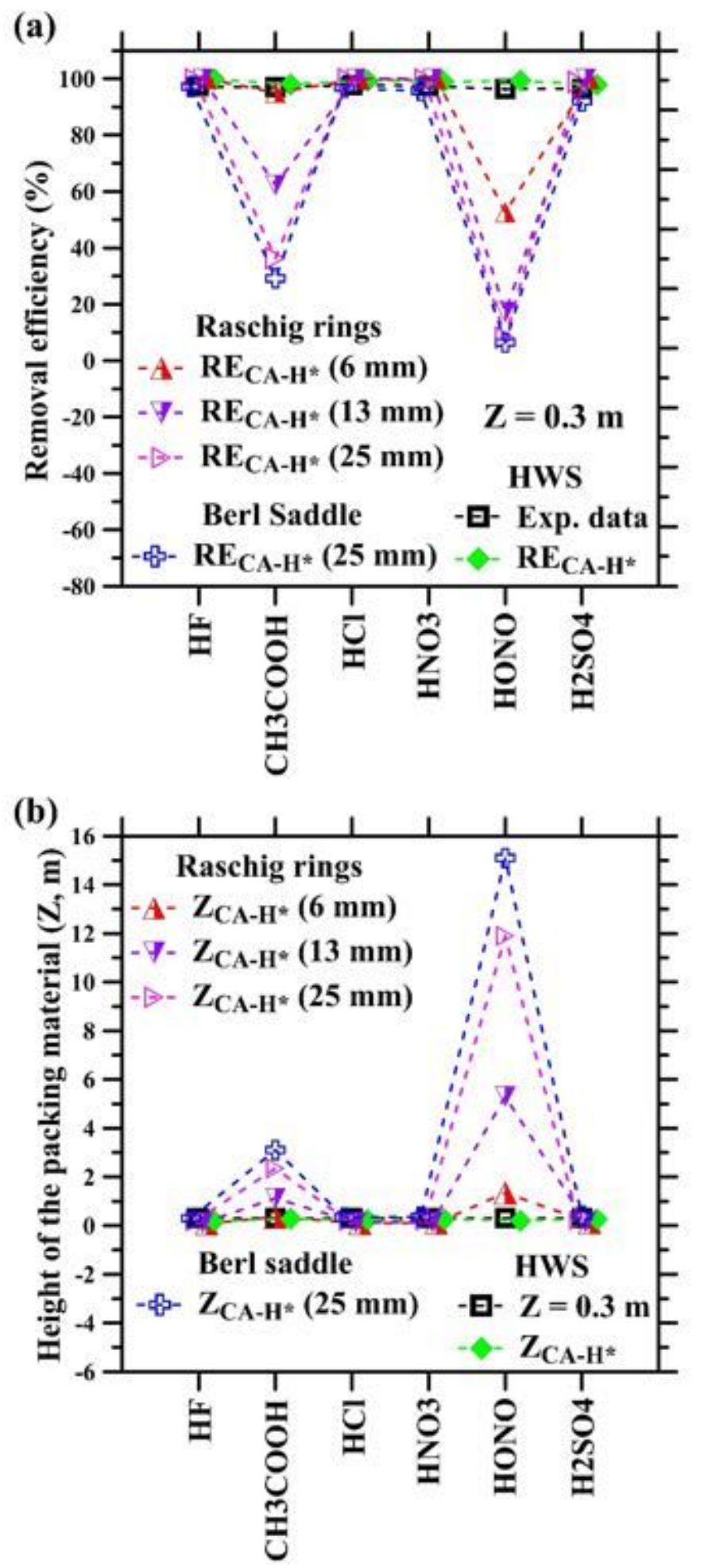

Figure 6

Comparison of a the theoretical removal efficiency, and $b$ the theoretical height of the traditional WS and the HWS (Note: the data are slightly shifted to avoid overlapping). 